\title{
Suggestibility Education and Sex Education for All People
}

\section{Press and Media Education}

The 10 Mantras of the Press and Media:

1. The press and media are unreliable about anything that is important and they make you a voyeur of non-being because most of it is untrue.

2. Celebrities, new casters, news reporters and moviemakers (including dissenting theologians) are fakes. It takes them hours to dress up for the role they are going to play. Celebrities are fakes!

3. Do not be suggestible remembering that people imitate what they see, repeat what they hear, and buy what they are told to buy from junk stuff to junk ideas -- so don't be gullible by believing the press and media which are nothing but flickering lights and ink smudged nonsense.

4. The press and media are frauds; they preach free speech but censor more than anyone; they claim tolerance but suppress all with which they do not agree; they proclaim equality but do not present fairly and equally all points of view; and they pretend diversity except for people and ideas not in agreement.

5. That is not me! That is not me! That is not me! (A special mantra to be said continuously while watching television, movies and intemet). Whatever you did already this morning was informationally more than all other moledular aggregates for billions of miles and billions of years so you are special as life is special -- Do not let the press and media influence you and thereby ruin it all.

6. Sex in all nature is to make babies and/or create family in the most developmentally favorable circumstances possible which, for humans, means in marriage between a man and a woman.

7. God is. He does not like sin. You have to have your sins forgiven and sinning is less if you do not believe the press and media about anything.

8. The people of the press and media do not include, believe, understand, accept, reflect, represent, portray or care about the common man (male or female) regardless of what claimed. They will never tell what they do not want the public to know. And you should never tell their pollsters the truth! The press and media are Satan's way of giving information.

9. You will never learn anything worth believing about the Roman Catholic Church from novels, movies, or the press and media.

Volume 4 Issue 3 - 2015
Dr. Samuel A Nigro M.D*
Retired, Assistant Clinical Professor Psychiatry, Case Western
Reserve University School of Medicine, USA
*Corresponding author: Dr. Samuel A Nigro M.D, Retired,
Assistant Clinical Professor Psychiatry, Case Western Reserve
University School of Medicine, 2517 Guilford Road, Cleveland
Heights, Ohio 44118, USA, Tel: 216 932-0575; Email:
sam@docnigro.com
Received: October 15, 2015 | Published: November 24,
2015

10. The press and media are the biggest frauds, liars, and tyrants ever to exist in the world. They may become believable after their editorial and executive meetings are on the internet.

\section{Sex Education}

Note to Teenagers: So you are getting a new body and it is going to do things you never dreamed of. Just remember your body is not a toy to play with or for others to play with. Anyone who wants to use you so that he can feel good is taking advantage of you even if it makes you feel good at the same time. "If it feels good, do it!" is an entrapment. Actually, the sex reflex outside of marriage is a form of excretion ("sexcretion" is accurate). There is much more to life than "feeling good" for 90 seconds. The sex reflex belongs in marriage and anyone who says different wants to exploit you, trick you and get you to accept a destructive and hidden agenda (They are using you as a toy). Do not let the sex reflex control your life and always mistrust and reject those who say otherwise. Do not be suggestible or gullible about anything you see or hear. The early teenage and young adult body is so attractive and stimulating that, when not treated with dignity, it can be a violation of your privacy and an intrusion into the privacy of others. So dress appropriately without exploitative ideas resulting and with class ("personhood" which at least minimally means you wear decent clothes). You have no right to force your sexuality on others and no one has any right to force their sexuality onto you. Protect and enjoy your new adult body. That way, your body will last longer and your life will be better if you keep yourself for marriage. Do not be suggestible. Do not be gullible. Be smart, dignified, classy and safe with your new body. It is not a toy for anyone to play with. 